\title{
Chemical Composition and Antioxidant Effect of Mentha rotundifolia Extracts
}

\author{
Ferdjioui Siham $^{1, *}$, Belhattab Rachid ${ }^{1}$, Raed M Al-Zoubi ${ }^{2}$
}

Ferdjioui Siham ${ }^{1, *}$, Belhattab Rachid', Raed M Al-Zoubi

'Department of Biochemistry, Laboratory of Applied Microbiology University Ferhat Abbas Setif-1,19000 Setif, ALGERIA.

2Department of Biochemistry, Laboratory of Applied Microbiology University Ferhat Abbas Setif-1,19000 Setif, ALGERIA.

${ }^{3}$ Department of Chemistry. Jordan University of Science and Technology, Irbid, JORDAN.

Correspondence

Ms. Ferdjioui Siham

Department of Biochemistry, Laboratory of Applied Microbiology University Ferhat Abbas Setif-119000 Setif, ALGERIA.

Phone no : +213-664-585442

E-mail: ferdjioui_89@yahoo.fr

History

- Submission Date: 05-12-2018;

- Review completed: 28-01-2019;

- Accepted Date: 12-02-2019

DOI : 10.5530/pj.2019.11.83

Article Available online

http://www.phcogj.com/v11/i3

\section{Copyright}

(C) 2019 Pharmacognosy Journal. This is an open-access article distributed under the terms of the Creative Commons Attribution 4.0 International license.

\begin{abstract}
Aim: This report was aimed to investigate both the chemical composition and the antioxidant activity of two extracts from Mentha rotundifolia aerial parts. Methods: Aqueous and acetonic extracts were obtained by decoction and Soxhlet apparatus, respectively. Total polyphenols contents were determined using Folin- Ciocalteu reagent whereas flavonoids were evaluated by $\mathrm{AlCl}_{3}$ method. LC-MS/MS method was carried out to reveal the phytochemical composition of extracts. Some tests were used to evaluate the in vitro antioxidant activity of extracts such as DPPH free radical scavenging assay, $\mathrm{ABTS}^{+}$radical cation decolorization assay, $\mathrm{OH}^{*}$ radical scavenging assay, ferrous ion chelating, reducing power and $\beta$-caroten/linoleic acid bleaching assay. Results: The results showed that the aqueous extract was richer on polyphenols and flavonoids comparing to the acetonic extract. The analysis by LC-MS/MS allowed to identify many phenolic compounds in extracts, predominated by rosmarinic acid. In addition, the extracts were found to possess a significant antioxidant activity. Conclusion: Accordingly, it can be concluded that $M$. rotundifolia is quite rich in phenolic compounds and has a good antioxidant activity.

Key words: Mentha rotundifolia, Extraction, Phenolic compounds, LC-MS/MS, Antioxidant activity.
\end{abstract}

\section{INTRODUCTION}

It is admitted that chronic diseases, as well as neurodegenerative pathologies such as cancer, cardiovascular diseases, Alzheimer's and other physiological disorders, are associated with the oxidant stress caused by free radicals and other oxidant. ${ }^{1}$ An antioxidant can be broadly defined as any substance that delays or inhibits oxidative damage to a target, herbal plants are considered as good antioxidants since ancient times. ${ }^{2}$ Plants of the Lamiaceae family constitute one of the major sources of gastronomic and medicinal plants all over the world. One of the important genera belonging to this family is the genus Mentha which is composed of around 19 geographically widespread species and 13 named hybrids. ${ }^{3}$ M. rotundifolia is one of these species and is largely used in Algerian as well as in Mediterranean traditional medicine. ${ }^{4}$

\section{MATERIALS AND METHODS}

\section{Plant material}

The aerial parts of $M$. rotundifolia were collected during 2015 in the region of Djemila, Wilaya of Setif (Algeria). The collected material was identified by Pr. Laouer $\mathrm{H}$ from the Laboratory of Botanical Sciences, F. A. Setif1 University. The plant material was then air dried at room temperature and away from humidity.

\section{Chemicals}

All solvents and reagents used in this study were obtained from Sigma-Aldrich (Germany), Fluka and Merck.

\section{Extraction}

The aqueous extract of $M$. rotundifolia was obtained $15 \mathrm{~min}$ in distilled water, filtered and the solvent was evaporated to get the aqueous extract. The acetonic extract was obtained from $20 \mathrm{~g}$ of the plant material powder mixed with $200 \mathrm{~mL}$ of acetone, using Soxhlet extractor for $6 \mathrm{~h}$. Thereafter, the extract was filtered and evaporated to dryness under vacuum at $40^{\circ} \mathrm{C}$ using a rotary evaporator.

\section{Determination of total polyphenols}

The amount of total phenolics in the extracts of $M$. rotundifolia was determined according to the method of Li et al. (2007). Briefly, $200 \mu \mathrm{L}$ of plant extracts solutions $(1.0 \mathrm{mg} / \mathrm{mL})$ were mixed with 1.0 $\mathrm{mL}$ of Folin- Ciocalteu reagent (10.0\%) for 4 mins. $800 \mu \mathrm{L}$ of aqueous $\mathrm{Na}_{2} \mathrm{CO}_{3}(7.5 \%)$ solution were added. The mixture was kept at room temperature for $2 \mathrm{~h}$ and then the absorbance was measured at $765 \mathrm{~nm}$. The results were expressed as $\mu \mathrm{g}$ Gallic acid equivalent (GAE)/mg of extract. by decoction of the grinded plant material $(100 \mathrm{~g})$ for

Cite this article: Siham F, Rachid B, Al-Zoubi RM. Chemical Composition and Antioxidant Effect of Mentha rotundifolia Extracts. Pharmacog J. 2019;11(3):521-6. 


\section{Determination of total flavonoids}

Total flavonoids content in $M$. rotundifolia extracts was determined by aluminum chloride colorimetric method. ${ }^{6} \mathrm{~A}$ volume of $1.0 \mathrm{~mL}$ of each extract was mixed with $1.0 \mathrm{~mL}$ of $\mathrm{AlCl}_{3}$ solution in methanol $(2.0 \%)$. After incubation for $30 \mathrm{~min}$ at room temperature, the absorbance of the reaction mixture was measured at $430 \mathrm{~nm}$. The total flavonoids contents of the extracts were expressed as $\mu \mathrm{g}$ quercetin equivalent $/ \mathrm{mg}$ of extract.

\section{Identification and Quantification of Individual Phenolic Compounds using Liquid Chromatography Mass Spectrometry (LC/MS/MS)}

The analyses of extracts by LC-MS/MS were performed in Pharmaceutical Research Center - Jordan University of Science and Technology using an Agilent 1200 chromatography system (Agilent 1200, Agilent Technologies, Wilmington, DE, USA) equipped with mass detector API-3200.

The extracts and phenolic standard were dissolved in methanol at the concentration of $(1.0 \mathrm{mg} / \mathrm{mL})$ and injected onto a $\mathrm{C}_{18}$ column Agilent zorbax $150 \mathrm{~mm}$ X $4.6 \mathrm{~mm}$. The analysis was performed using a gradient solvent system with aqueous-formic acid $(0.10 \%)$ as solvent (A) and acetonitrile (100\%) as solvent (B). A five-step linear gradient elution with a total run time of $35 \mathrm{~min}$ was employed, the gradient elution was realized by decreasing solvent A to $10 \%$ and increasing solvent B to $90 \%$. An injection volume of $20 \mu \mathrm{L}$ at a constant flow rate of $1.0 \mathrm{~mL} / \mathrm{min}$ was used for each analysis.

The entire flow from the High-performance Liquid Chromatography (HPLC) was directed into a triple- quadrupole mass spectrometer (API 3200; MDS Sciex, Concord, ON, Canada). The mass spectral data were acquired in negative ion mode with a capillary voltage of $4500 \mathrm{~V}$, an Electrospray Ionization (ESI) ion source, a cone voltage of $70 \mathrm{~V}$, a collision energy of $35 \mathrm{eV}$, a drying temperature of $650^{\circ} \mathrm{C}, \mathrm{N}_{2}$ as the drying gas with a flow rate of $4.0 \mathrm{~L} / \mathrm{min}$ and Analyst software version 6 .

A diode-array UV detector was used to scan between 200 and $400 \mathrm{~nm}$ to evaluate the contents of individual phenolic compounds and the eluted samples and standards were detected at $280 \mathrm{~nm}$.

\section{Antioxidant Activity}

\section{2,2-Diphenyl-1-picrylhydrazyl (DPPH') Radical}

Scavenging Assay

DPPH radical-scavenging activity of extracts was determined according to the method of Que et al. (2006). ${ }^{7}$ Briefly, $1.0 \mathrm{~mL}$ of each plant extracts at different concentrations was added to $1.0 \mathrm{~mL}$ DPPH solution $(0.01 \mathrm{M}$ in methanol). The mixture was shaken and left to stand for $30 \mathrm{~min}$ at room temperature in the dark. The absorbance was measured at $517 \mathrm{~nm}$. The capability to scavenge the DPPH• radical was calculated using the following equation.

Percentage of inhibition $\left.(\%)=\left[\left(\mathrm{A}_{\text {control }}-\mathrm{A}_{\text {sample }}\right) / \mathrm{A}_{\text {control }}\right)\right] \times 100$.

\section{$\mathrm{OH} \cdot$ Scavenging Activity Assay}

Hydroxyl radical $\left(\mathrm{OH}^{*}\right)$ scavenging ability was measured according to the literature procedure of Ates et al. 2008, ${ }^{8}$ with slight modifications. The reaction mixture $(3 \mathrm{ml})$ contained $1 \mathrm{ml}$ of $\mathrm{FeSO}_{4}(1.5 \mathrm{mM}), 0.7 \mathrm{ml}$ of $\mathrm{H}_{2} \mathrm{O}_{2}(6 \mathrm{mM}), 0.3 \mathrm{ml}$ of sodium salicylate $(20 \mathrm{mM})$ and varying concentrations of extracts or standard antioxidant (BHA). This mixture was incubated at $37^{\circ} \mathrm{C}$ for $1 \mathrm{~h}$; afterwards, the absorbance of the hydroxylated salicylate complex was measured at $562 \mathrm{~nm}$. The scavenging rate was calculated as percentage inhibition effect.

$$
\left.\mathrm{I}(\%)=\left[\left(\mathrm{A}_{\text {control }}-\mathrm{A}_{\text {sample }}\right) / \mathrm{A}_{\text {control }}\right)\right] \times 100 .
$$

\section{$\mathrm{ABTS}^{+}$Radical Cation(s) Decolorization Assay}

The spectrophotometric analysis of ABTS radical scavenging activity was determined according to Re et al. (1999) ${ }^{9}$ with some modification. ABTS was dissolved in water to a $7.0 \mathrm{mM}$ concentration. ABTS radical cation (ABTS $^{*}$ ) was produced by reacting ABTS stock solution with $2.45 \mathrm{mM}$ potassium persulfate (Final concentration) and allowing the mixture to stand in the dark at room temperature for $12-16 \mathrm{~h}$ before using. The radical was found to be stable in this form and for more than two days when stored in dark at room temperature. For the study, the ABTS ${ }^{\bullet+}$ solution was diluted with ethanol, to an absorbance of 0.70 at $734 \mathrm{~nm} .1 .0 \mathrm{~mL}$ of $\mathrm{ABTS}^{*+}$ solution was added to $50.0 \mu \mathrm{L}$ of the extract solution at different concentrations. After $30 \mathrm{~min}$, percentage inhibition was calculated for each concentration at $734 \mathrm{~nm}$. Appropriate solvent blanks were used in each assay. The $\mathrm{ABTS}^{+}$scavenging ability as percentage was calculated as.

$$
\left.\mathrm{I}(\%)=\left[\left(\mathrm{A}_{\text {control }}-\mathrm{A}_{\text {sample }}\right) / \mathrm{A}_{\text {control }}\right)\right] \times 100 .
$$

\section{Metal ion chelating assay}

The estimation of iron ions chelation of the extracts was performed according to Le et al. (2007). ${ }^{10}$ Briefly, an aliquot $(500 \mu \mathrm{L})$ of different concentrations of extracts was mixed with $100 \mu \mathrm{L} \mathrm{FeCl}_{2}(0.6 \mathrm{mM})$ and $900 \mu \mathrm{L}$ methanol. After $5 \mathrm{~min}$ incubation, the reaction was initiated by the addition of $100 \mu \mathrm{L}$ ferrozine $(5 \mathrm{mM})$. The mixture was shaken vigorously and after $10 \mathrm{~min}$ incubation period the absorbance of the solution was measured at $562 \mathrm{~nm}$. EDTA was used as positive control. The ratio of inhibition of ferrozine- $\mathrm{Fe}^{2+}$ complex formation was calculated as follows.

$$
\mathrm{I} \%=\left[\left(\mathrm{A}_{\text {control }}-\mathrm{A}_{\text {sample }}\right) / \mathrm{A}_{\text {control }}\right] \times 100 .
$$

\section{Reducing power assay}

The reducing power of extracts was determined according to the method cited by Beyhan et al. (2010). ${ }^{11} 1.0 \mathrm{~mL}$ of extracts at different concentrations was mixed with $2.5 \mathrm{~mL}$ phosphate buffer ( $\mathrm{pH} 6.6)$ and $2.5 \mathrm{~mL}$ of $1.0 \%$ potassium ferricyanide $\left[\mathrm{K}_{3} \mathrm{Fe}(\mathrm{CN})_{6}\right]$ solution. The mixture was incubated at $50^{\circ} \mathrm{C}$ for $20 \mathrm{~min}, 2.5 \mathrm{~mL}$ of $10 \%$ trichloroacetic acid was added to the mixture. After vigorous agitation, $2.5 \mathrm{~mL}$ of this solution was mixed with $2.5 \mathrm{~mL}$ of distilled water and $0.5 \mathrm{~mL} \mathrm{FeCl}_{3}(0.1 \%)$, the absorbance was measured at $700 \mathrm{~nm}$. The BHA was used as positive control. The $\mathrm{EC}_{50}$ for this test is defined as the effective concentration at which the absorbance is 0.5 .

\section{$\beta$-Carotene/ Linoleic Acid Bleaching Assay}

The ability of extracts to prevent bleaching of $\beta$-carotene was assessed as described by Miraliakbari and Shahidi (2008). ${ }^{12}$ A stock solution of $\beta$-carotene/linoleic acid was prepared by dissolving $0.5 \mathrm{mg}$ of $\beta$-carotene in $1.0 \mathrm{~mL}$ of Chloroform, $25 \mu \mathrm{L}$ of linoleic acid and $200 \mathrm{mg}$ of Tween 40 . The Chloroform was completely evaporated under vacuum in a rotatory evaporator at $40^{\circ} \mathrm{C}, 100 \mathrm{~mL}$ of distilled water saturated with oxygen were added, $2500 \mu \mathrm{L}$ of this reaction mixture were dispensed into test tubes $350 \mu \mathrm{L}$ of the various extracts, prepared at $2.0 \mathrm{mg} / \mathrm{mL}$ concentrations were added and the emulsion system was incubated for $48 \mathrm{~h}$ at room temperature. The same procedure was repeated with the positive control (BHA) and blanks $\left(\mathrm{MEOH}\right.$ and $\left.\mathrm{H}_{2} \mathrm{O}\right)$. The covered tubes were incubated at $50^{\circ} \mathrm{C}$ and the absorbance was measured at $470 \mathrm{~nm}$ each $15 \mathrm{~min}$ during $120 \mathrm{~min}$. The antioxidant activity was calculated as following equation. 


$$
\mathrm{AA} \%=\mathrm{A}_{\mathrm{t}} / \mathrm{A}_{0} * 100 .
$$

$\mathrm{A}_{0}$ : Absorbance of the sample at $\mathrm{t}_{0}$.

$A_{t}$ : Absorbance of the sample after 120 min of incubation.

\section{Statistical analysis}

The results were presented as the mean of three repetitions ( \pm Standard deviation (SD)). Statistical analysis of data was performed by using the GraphPad Prism 5 program. The data were analyzed by one-way Analysis of variance (ANOVA). Significant differences between means and standards were determined by Dennett's test, the level of significance was set at $p<0.05$.

\section{RESULTS AND DISCUSSION}

\section{Phytochemical analyses}

The extraction of phenolic compounds from M. rotundifolia arial parts was realized by two methods. The aqueous extract was obtained by decoction at a yield of $14.2 \%$, whereas the acetonic extract obtained by soxhlet apparatus showed a yield of $3.08 \%$. The amount of polyphenols and flavonoids was determined using Folin Ciocalteu and aluminium chloride method respectively. The results shown in Table 1 indicated that the aqueous extract was richer in polyphenols and flavonoids than the acetonic extract.

\section{LC-MS/MS Analysis}

The qualitative and quantitative analysis of phenolic compounds in aqueous and acetonic extracts of $M$. rotundifolia was conducted by using LC-MS/MS analysis. Phenolic compounds were identified by comparison of retention times and spectra of each peak with those of known standards analyzed in the same conditions.

(Apigenin, isoquercetin, catechol, epicatechin, gallic acid, procyanidin B2, quercetin 3-O- galactoside, luteolin, chlorogenic acid, epigallocatechingallate, cyaninchlorid, myrtillin, quercetin, rutin, caffeicacid,ellagicacid, ferulic acid, hydroxybenzoic acid, p-coumaric acid, rosmarinic acid, syringic acid, transcinamaldehyde acid, vanilic acid and hypericin) (Figure 1).

Among the 24 standards used, the analysis led to the identification of 15 and 16 phenolic compounds (Flavonols, phenolic acids etc.) in the aqueous and the acetonic extracts respectively (Table 2), the predominant compound was rosmarinic acid at a rate of $6610 \mathrm{ng} / \mathrm{mL}$ and $6370 \mathrm{ng} / \mathrm{mL}$ in aqueous and acetonic extract respectively. This phenolic acid was the subject of several scientific studies which made it possible to determine its therapeutic effect as anticancer, ${ }^{13}$ antioxidant ${ }^{14}$ and anti-Alzheimer. ${ }^{15}$ A large diversity of molecules was observed in these extracts as phenolic acids (Chlorogenic acid, ferulic Acid, vanilic Acid), flavones and flavonols (Apigenin, luteolin, quercetin 3-O-galactoside). It is worth to note that the quantities of these compounds are different between extracts, these differences may be due to the method of extraction and the type of solvents. No previous work illustrates the chemical composition of aqueous and acetonic extracts of $M$. rotundifolia. However, there essential oil has been the subject of numerous phytochemical investigations belonging to different regions in the world. ${ }^{4,16}$

\section{Antioxidant activity}

Phenolic compounds have been shown to be responsible for the antioxidant effect of plant. The antioxidant activity of polyphenols was attributed to their redox properties, which allows them to act as reducing agents, hydrogen donators and singlet oxygen quenchers, some show metal chelation properties. ${ }^{17,18}$ Antioxidants can also prevent free radicals from forming, protect cells from free radical damage and enhance the body's

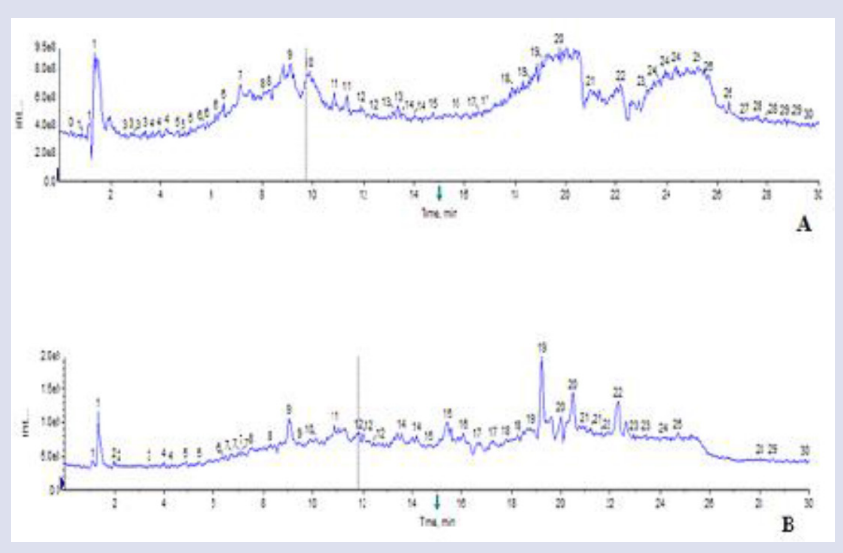

Figure 1: LC/MS Chromatogram of M. rotundifolia extracts (A): Aqueous extract, (B): Acetonic extracts.

Table 1: Amounts of Total Polyphenols and Flavonoids in M. rotundifolia Extracts.

\begin{tabular}{ccc}
\hline Extracts & $\begin{array}{c}\text { Polyphenols } \\
(\mu \mathrm{g} \mathrm{GAE} / \text { mg extract })\end{array}$ & $\begin{array}{c}\text { Flavonoids } \\
(\mu \mathrm{g} \text { QE/mg extract })\end{array}$ \\
\hline Aqueous extract & $154.15 \pm 1.95$ & $29.358 \pm 2.009$ \\
Acetonic extract & $113.7 \pm 2$ & $16.275 \pm 0.375$ \\
\hline
\end{tabular}

defense system and work to protect, lipids from peroxidation by radicals. ${ }^{19}$ In order to determine the mode of action of extracts; six different assays were used.

\section{$\mathrm{DPPH}$ 'free radical scavenging assay}

Substances which are able to donate hydrogen or an electron to DPPH', can be considered as antioxidants and therefore radicals scavengers. ${ }^{20}$ To determine the efficacy of extracts concentration providing 50\% inhibition $\left(\mathrm{IC}_{50}\right)$ was calculated from the plot of inhibition percentage against the extract concentration (Figure 2), noting that lower $\mathrm{IC}_{50}$ value indicates higher antioxidant activity. The results reveal that the DPPH radical-scavenging activity of acetonic extract was more marked than that of aqueous extract with $\mathrm{IC}_{50}$ of $15.066 \pm 0.449 \mu \mathrm{g} / \mathrm{mL}$ and $97.862 \pm$ $0.218 \mu \mathrm{g} / \mathrm{mL}$ for acetonic and aqueous extracts respectively. However, the effect of extracts was lower $(p<0.001)$ than that of BHA $\left(\mathrm{IC}_{50}\right.$ of $5.742 \pm 0.206 \mu \mathrm{g} / \mathrm{mL})$.

\section{$\mathrm{ABTS}^{+}$Radical Cation Scavenging Activity}

The ABTS radical scavenging action is known to be one of the various mechanisms for measuring antioxidant activity of food. This method was not only a rapid and reliable test of antioxidant capacity but also an advantageous assay applicable to both hydrophilic and lipophilic antioxidants/systems. ${ }^{21}$ As shown in Figure 3, the extracts have a good antioxidant effect with $\mathrm{IC}_{50}$ of $5.868 \pm 0.487 \mu \mathrm{g} / \mathrm{mL}$ and $22.026 \pm 0.759 \mu \mathrm{g} / \mathrm{mL}$ for aqueous and acetonic extract respectively. To evaluate the potency of extracts, the activity was compared with the synthetic antioxidant BHT, which presents the best potency $\left(\mathrm{IC}_{50}=2.745 \pm 0.180 \mu \mathrm{g} / \mathrm{mL}\right)$.

\section{$\mathrm{OH} \cdot$ Scavenging Activity Assay}

Among the Reactive Oxygen Species (ROS), hydroxyl radicals are the most reactive and are the predominant radicals generated endogenously 
Table 2: Phenolic Profile of $M$. rotundifolia Aqueous and Acetonic Extracts Identified by LC- MS/MS.

\begin{tabular}{|c|c|c|c|c|c|c|c|}
\hline & Compounds & $C_{1}(\mathrm{ng} / \mathrm{mL})$ & $C_{2}(n g / m L)$ & RT & $\mathrm{Q}_{1}$ & $\mathrm{Q}_{3}$ & MWT \\
\hline 1 & Gallic acid & l & l & 1.53 & 169 & 124.6 & 170.12 \\
\hline 2 & Catechol & I & l & 5.5 & 109 & 109 & 110.11 \\
\hline 3 & Chlorogenic acid & 77.4 & 197 & 5.94 & 353.155 & $190.4 / 84.8 / 93.1$ & 354.31 \\
\hline 4 & Vanilic acid & 67.8 & 260 & 6.38 & 166.66 & $107.8 / 151.2 / 151.7$ & 168.15 \\
\hline 5 & Procyanidin B2 & l & l & 6.4 & 577.1 & $407 / 289$ & 578.52 \\
\hline 6 & Hydroxybenzoic acid & 29.9 & 77.7 & 6.48 & 134.779 & $88.4 / 106.8 / 89.1$ & 135.12 \\
\hline 7 & Syringic acid & 95.1 & 197 & 6.48 & 196.718 & $120.4 / 120.7 / 152.3$ & 198.17 \\
\hline 8 & Caffeic acid & 23.4 & 50.8 & 6.5 & 178.465 & $134.2 / 106.4 / 89.1$ & 18.16 \\
\hline 9 & Epicatechin & I & l & 6.57 & 289.1 & 108.8 & 290.3 \\
\hline 10 & Epigallocatechin gallate & 1 & l & 6.66 & 456.579 & $168.2 / 168.5 / 124.8$ & 458.372 \\
\hline 11 & Rutin & 64.8 & 139 & 6.84 & 609.419 & 299/299.9/270.9 & 610.52 \\
\hline 12 & Quercetin3-O-galactoside & 45.6 & 32.7 & 7 & 463 & 301 & 464.379 \\
\hline 13 & Isoquercitrin & 20 & 1 & 7 & 464.9 & 300 & 464.4 \\
\hline 14 & Myrtillin & 0.414 & 18.1 & 7.01 & 462.178 & $299.8 / 270.8 / 254.7$ & 500.8 \\
\hline 15 & P-Coumaric acid & 75.8 & 262 & 7.06 & 162.756 & $118.8 / 118.1 / 92.7$ & 164.16 \\
\hline 16 & Ferulic acid & 93 & 99.2 & 7.2 & 192.807 & $133.9 / 133.4 / 177.8$ & 194.18 \\
\hline 17 & Rosmarinic acid & 6610 & 6370 & 7.38 & 358.319 & $160.7 / 161 / 132.7$ & 360.32 \\
\hline 18 & Transcinamaldehyde acid & l & 171 & 7.95 & 131.797 & $103.7 / 102.8 / 101.9$ & 132.16 \\
\hline 19 & Luteolin & 40.9 & 263 & 8 & 285 & 217 & 286.24 \\
\hline 20 & Cyanin chloride & 59.9 & 438 & 8 & 286.198 & $133.4 / 132.8 / 150.6$ & 287.1 \\
\hline 21 & Ellagic acid & I & 1 & 8.01 & 300.703 & $149.7 / 150.6 / 149.9$ & 302.197 \\
\hline 22 & Quercetin & I & 8.09 & 8.01 & 300.604 & 150.4 & 302.2 \\
\hline 23 & Apigenin & 9.12 & 139 & 8.4 & 269 & 151 & 270.12 \\
\hline $24-$ & Hypericin & l & l & 10.53 & 503 & 405 & 504.45 \\
\hline
\end{tabular}

$\mathrm{C}_{1}$ : Concentration of phenolic compound in aqueous extracts; $\mathrm{C}_{2}$ : Concentration of phenolic compound in acetonic extract, $\mathrm{Q}_{1}$ : Compound molecular weight, $\mathrm{Q}_{3}$ : Fragment Molecular Weight, MWT: Molecular Weight.

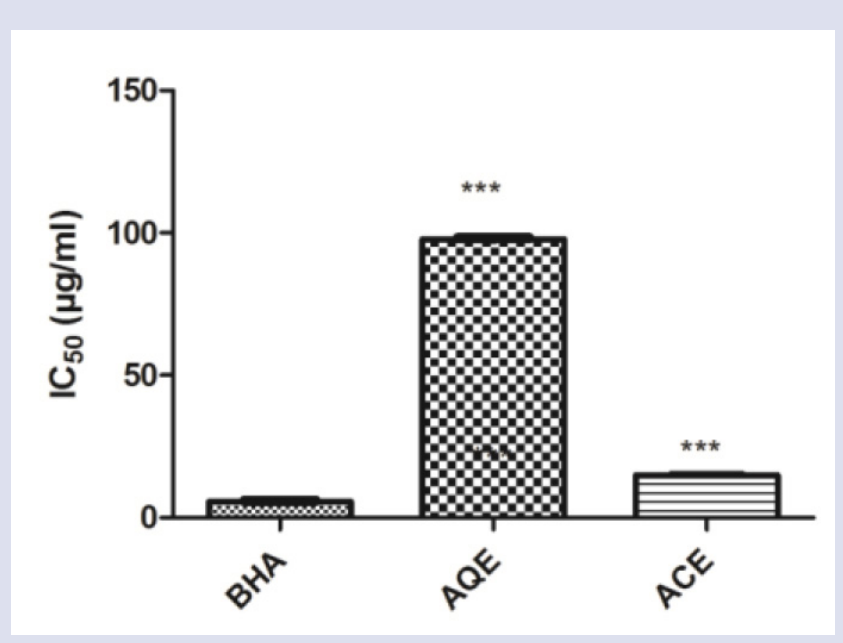

Figure 2: DPPH Scavenging Activity of M. rotundifolia Extracts Expressed as IC ${ }_{50}$ Values, AQE: Aqueous extract, ACE: Acetonic Extract. Values are the mean $\pm \mathrm{SD}(n=3)$. Comparisons are made with BHA. ***: $p \leq 0.001$.

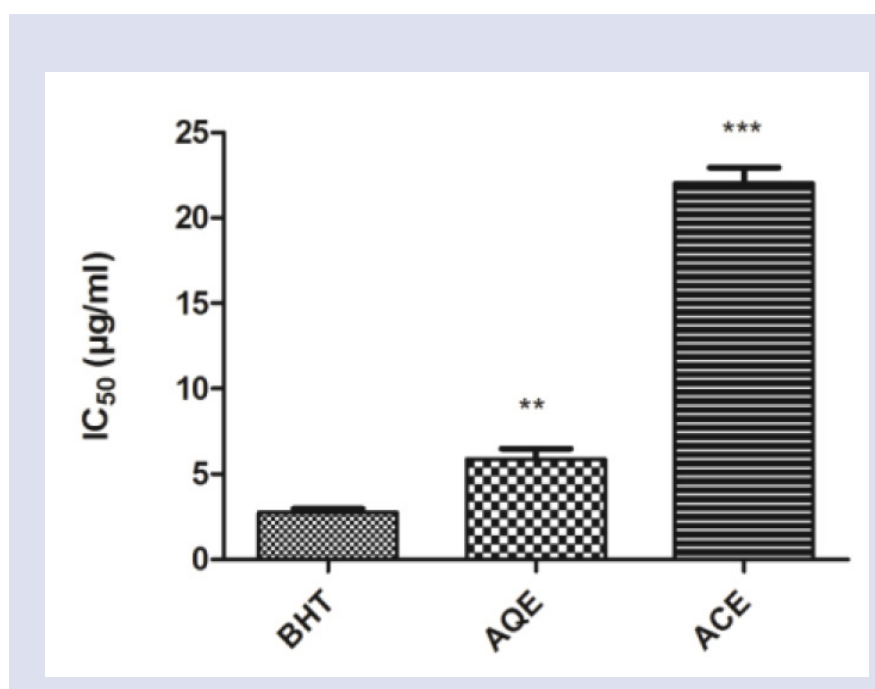

Figure 3: $\mathrm{ABTS}^{+}$Scavenging Activity of M. rotundifolia Extracts Expressed as IC ${ }_{50}$ Values. AQE: Aqueous Extract, ACE: Acetonic Extract. Values are the mean $\pm \mathrm{SD}(n=3)$. Comparisons are made with $\mathrm{BHT}$ ${ }^{* *} p<0.01,{ }^{* * *}: p \leq 0.001$. 


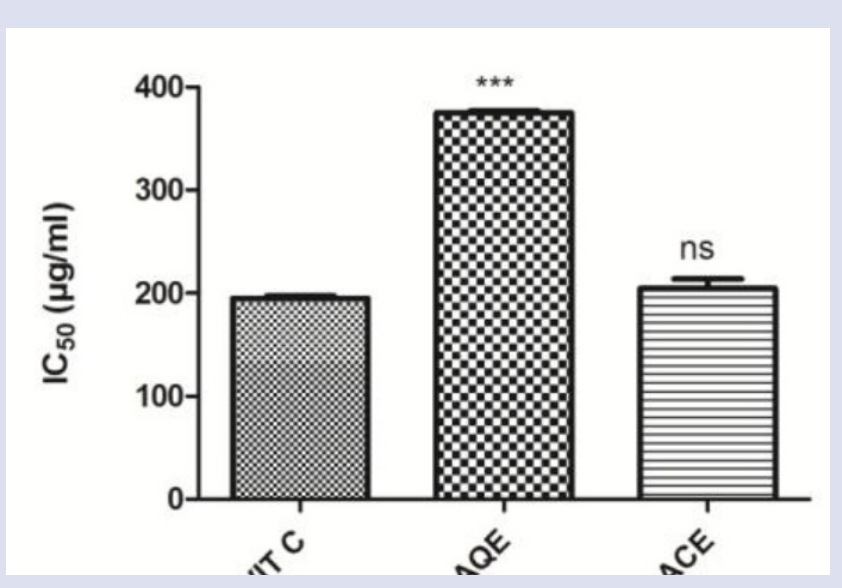

Figure 4: $\mathrm{IC}_{50}$ Values of $M$. rotundifolia Extracts for $\mathrm{OH}^{-}$Scavenging Activity. AQE: Aqueous Extract, ACE: Acetonic extract. Values were Expressed as the mean $\pm \mathrm{SD}(n=3)$. Comparisons are made with Vitamin C, ns: No significant difference, ${ }^{* * *}: p \leq 0.001$. during aerobic metabolism to initiate cell damage in vivo. ${ }^{22}$ The results (Figure 4) indicate that the most potent scavenger of $\mathrm{OH} \cdot$ Radical was observed with vitamin $\mathrm{C}\left(\mathrm{IC}_{50}=194.868 \pm 1.836 \mu \mathrm{g} / \mathrm{mL}\right)$ followed by ACE $\left(\mathrm{IC}_{50}=204.355 \pm 3.925 \mu \mathrm{g} / \mathrm{mL}\right)$ and $\mathrm{AQE}\left(\mathrm{IC}_{50}=377.232 \pm 4.995 \mu \mathrm{g} / \mathrm{mL}\right)$.

\section{Metal Chelating Activity}

Iron is essential for life as it is required for oxygen transport, respiration and for activity of many enzymes. Chelating agents are effective as secondary antioxidants since they decrease the redox potential, thereby, stabilizing the oxidized form of the metal ion. Decrease in the red color of the complex ferrozine- $\mathrm{Fe}^{2+}$ indicates high radical scavenging activity of the compound. ${ }^{23}$ To compare the effect of aqueous, acetonic extracts and standard (EDTA), the values of $\mathrm{IC}_{50}$ were calculated, which demonstrated that EDTA possess the most powerful chelating activity $\left(\mathrm{IC}_{50}=6.273 \pm 0.288 \mu \mathrm{g} / \mathrm{mL}\right)$ followed by the aqueous extract $\left(\mathrm{IC}_{50}=128.155 \pm 5.887 \mu \mathrm{g} / \mathrm{mL}\right)$. However, the acetonic extract didn't reach $50 \%$ chelating activity and presents maximal activity of $41.433 \pm 2.518 \%$ at $468.75 \mu \mathrm{g} / \mathrm{mL}$.

\section{Reducing Power}

The presence of reductants such as antioxidant substances in the samples causes the reduction of the $\mathrm{Fe}^{3+} /$ ferricyanide complex to the ferrous form. Therefore, $\mathrm{Fe}^{2+} \mathrm{can}$ be monitored by measuring the formation of Perl's Prussian blue at $700 \mathrm{~nm} .{ }^{10}$ In this test, The $\mathrm{EC}_{50}$ values indicated that the BHA showed the good reducing power $\left(\mathrm{EC}_{50}=13.997 \pm 0.408 \mu \mathrm{g} / \mathrm{mL}\right)$, followed by the aqueous extract $\left(\mathrm{EC}_{50}=18.809 \pm 0.369 \mu \mathrm{g} / \mathrm{mL}\right)$ and finely the acetonic extract $\left(\mathrm{EC}_{50}=25.83 \pm 0.208 \mu \mathrm{g} / \mathrm{mL}\right.$ ) (Figure 5).

\section{$\beta$-Carotene/ Linoleic Acid Bleaching Assay}

In this test, the antioxidants give hydrogen molecules to the media which stops the peroxidation of linoleic acid, the hydrogen also scavenge singlet oxygen responsible of linoleic acid peroxidation. ${ }^{23}$ The lowest $\beta$-carotene discoloration rate exhibited the highest antioxidant activity, Figure 6 shows the lipid peroxidation inhibitory activity of M. rotundifolia extracts by the $\beta$ carotene-linoleic acid assay. The inhibition ratios of the oxidation of linoleic acid by the acetonic and aqueous extracts, were giving approximately the same percentage of inhibition ratio, 79.778 $1.812 \%$ and $84.666 \pm 0.963 \%$ respectively. However, the activity of BHA is more effective $(89.479 \pm 0.055 \%)$.

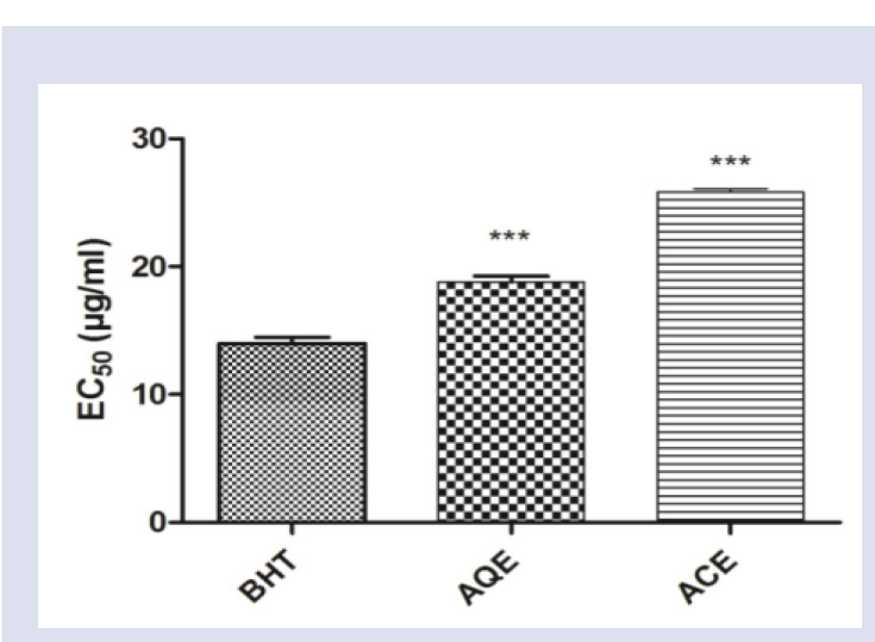

Figure 5: $\mathrm{EC}_{50}$ Values of $M$. rotundifolia Extracts for Reducing Power Test. AQE: Aqueous Extract, ACE: Acetonic Extract. Values were Expressed as the mean $\pm S D(n=3)$. Comparisons are made against BHT. ${ }^{* * *}: p \leq 0.001$.

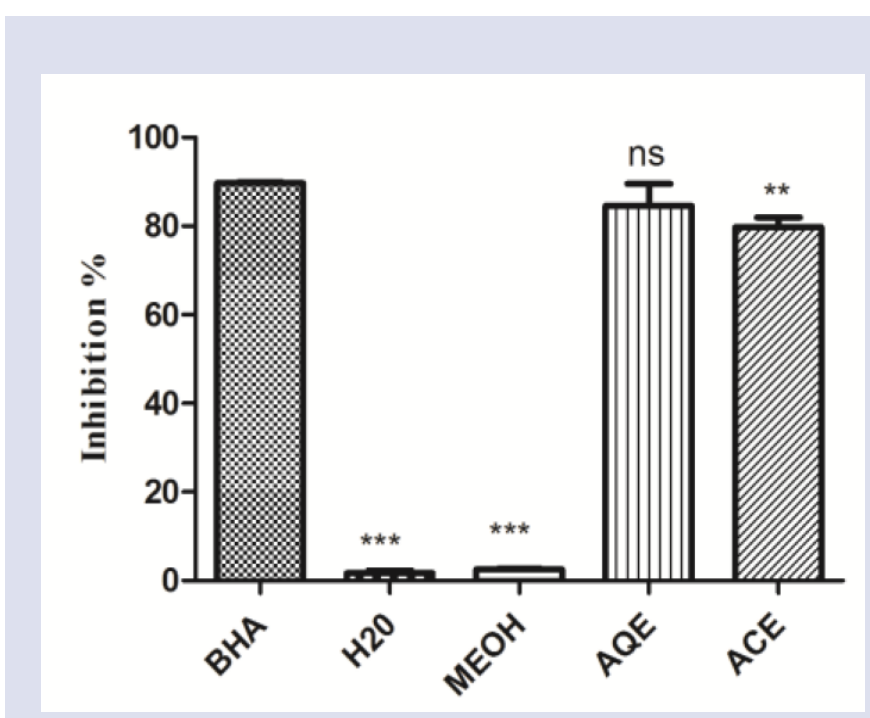

Figure 6: : Relative antioxidant activities of $M$. rotundifolia extracts and BHA in $\beta$-carotene/linoleic acid system after 2h. AQE: Aqueous Extract, ACE: Acetonic Extract. Values were expressed as the mean $\pm S D(n=3)$. Comparisons are made against BHA, ns: No significant difference, ${ }^{* *} p<0.01,{ }^{* * *}: p \leq 0.001$.

Our results demonstrate the good antioxidant effect of $M$. rotundifolia extracts with al tests, this effect may be due to abundance of different flavonoids and phenolic compounds. The antioxidant activity of flavonoids depends on the functional group arrangement of nuclear structures. Configurations, substitutions and amounts of hydroxyl groups substantially affect some mechanisms of antioxidant activity. ${ }^{24}$ a synergistic or antagonistic effect between the major and minor compounds also proposed to explain the effect of the extracts.

\section{CONCLUSION}

In this research we studied the chemical composition and the antioxidant activity of M. rotundifolia aqueous and acetonic extracts. The LC-MS/MS technique is used to identify numerous phenolic compounds, which are 
known for their therapeutic effects. Moreover, a good antioxidant activity of extracts was confirmed by many tests. According to our results, it is clear that this plant is good for human. Further studies in vitro and in vivo are necessary to identify the biological roles of individual compounds of extracts and other biological properties of this plant.

\section{ACKNOWLEDGMENT}

This study was supported by grants from Ministry of higher education and scientific research. We would like also to thank Ashraf Mutlaq (Pharmaceutical Research Center - Jordan University of Science and Technology) for performing the chemical analysis.

\section{CONFLICT OF INTEREST}

The authors declare no conflict of interest.

\section{ABBREVIATIONS}

DPPH: 2,2-diphenyl-1-picrylhydrazyl; ABTS: 2.2'-Azino-bis(3-ethylbenzenothiazoline 6-sulfonic acid); BHT: 2,6-di-tert-butyl-4-hydroxycarboxylic acid; BHA: Butylatedhydroxy anisole.

\section{REFERENCES}

1. Benites RSR, Formagio ASN, Argandoña EJS, Volobuff CRF, Trevizan LNF, Vieira $\mathrm{MC}$, et al. Contents of constituents and antioxidant activity of seed and pulp extracts of Annona coriacea and Annona sylvatica. Braz J Biol. 2015;75(3):685-91.

2. Badakhshan MP, Subramanion LJ, Lachimanan YL, Yeng C, Sreenivasan S. Antioxidant activity of methanol extracts of different parts of Lantana camara. Asian Pac J Trop Biomed. 2012;2(12):960-5

3. Kizil S, Hasini N, Tolan V, Kilinç E, Yüksel U. Mineral content, essential oil components and biological activity of two Mentha species (M. piperita L., M. spicata L.) Turkish J Field Crops. 2010;15(2):148-53.

4. Brada M, Bezzina M, Marlier M, Lognay G. Chemical composition of the leaf oil of Mentha rotundifolia (L.) from Algeria. J Essent Oil Res. 2006;18(6):663-5.

5. Li HB, Cheng KW, Wong CC, Fan KW, Chen F, Jiang Y. Evaluation of antioxidant capacity and total phenolic content of different fractions of selected microalgae. Food Chem. 2007;102(3):771-6.

6. Kosalec I, Bakmaz M, Pepeljnjak S, Vladimir-Knezevic S. Quantitative analysis of the flavonoids in raw propolis from northern Croatia. Acta Pharm. 2004;54(1):65-72.

7. Que F, Mao L, Pan X. Antioxidant activities of five Chinese rice wines and the involvement of phenolic compounds. Food Res Inter. 2006;39(5):581-7.
8. Ates B, Abraham L, Ercal N. Antioxidant and free radical scavenging properties of $\mathrm{N}$-acetylcysteine amide (NACA) and comparison with N-acetylcysteine (NAC) Free Radical Res. 2008;42(4):372-7.

9. Re R, Pellegrini N, Proteggente A, Pannala A, Yang M, Rice-Evans C. Antioxidant activity applying an improved ABTS radical cation decolorization assay. Free Rad Biol Med. 1999:26(9-10):1231-7.

10. Le K, Chiu F, Ng K. Identification quantification of antioxidants in Fructuslycii. Food Chem. 2007;105(1):353-63.

11. Beyhan O, Elmastas M, Gedikli F. Total phenolic compounds and antioxidant capacity of leaf, dry fruit and fresh fruit of feijoa (Accasellowiana, Myrtaceae). J Med Plants Res. 2010;4(11):1065-72.

12. Miraliakbari $H$, Shahidi F. Antioxidant activity of minor components of tree nut oils. Food Chemistry. 2008:111(2):421-7.

13. Hossan S, Rahman S, Bashar A, Jahan R, Al-Nahain A, Rahmatulla M. Rosmarinic acid: a review of its anticancer action. W J Pharm Sci. 2014;3(9):57-70.

14. Bhatt R, Mishra N, Bansal PK. Phytochemical, pharmacological and pharmacokinetics effects of rosmarinic acid. J Pharm Scilnnov. 2013;2(2):28-34.

15. Habtemariam S. Molecular pharmacology of rosmarinic and salvianolic acids: Potential seeds for Alzheimer's and vascular dementia drugs. Int J Mol Sci. 2018;19(458):1-25

16. Derwich E, Benziane Z, Taouil R, Senhaji O, Touzani M. Comparative essential oil composition of leaves of Mentha rotundifolia and Mentha pulegium a traditional herbal medicine in Morocco. Am Eurasian J Sustain Agric. 2010;4(1):47-54.

17. Vladimir-Kneževic S, Blažekovic B, Štefan MB, Alegro A, Koszegi T, Petrik J. Antioxidant activities and polyphenolic contents of three selected Micromeria species from Croatia. Molecules. 2011;16(2):1454-70.

18. Proestos C, Lytoudi K, Mavromelanidou OK, Zoumpoulakis P, Sinanoglou VJ. Antioxidant capacity of selected plant extracts and their essential oils. Antioxidants. 2013;2(1):11-22.

19. Lamina S, Ezema Cl, Theresa Al, Anthonia EU. Effects of free radicals and antioxidants on exercise performance. Oxid Antioxid Medical Sci. 2013;2(2):83-91.

20. Kang SN, Goo YM, Yang MR, Hag IRI, Cho JH, KimS, Lee H. Antioxidant and antimicrobial activities of ehanol extract from the stem and leaf of $/ \mathrm{mpa}$ tiens balsamina L. (Balsaminaceae) at different harvest times. Molecules. 2013;18(6):6356-65.

21. Sivakumar $\mathrm{CHV}$, Meera I. Antioxidant and Biological Activities of Three Morphotypes of Murrayakoenigii L. from Uttarakhand. J Food Process Technol. 2013;4(7):1-7.

22. Sasikumar $V$, Kalaisezhiyen $P$. Evaluation of free tadical scavenging activity of various leaf extracts from Kedrostis foetidissima (Jacq.) Cogn. Biochem Anal Biochem. 2014;3(2):1.

23. Kaplaner $\mathrm{E}$, Singec $\mathrm{MH}$, Öztürk $\mathrm{M}$. Fatty Acid Composition and Antioxidan Activity of Tricholomalmbricatum and T. Focale. Turkish Journal of AgricultureFood Science and Technology. 2017;5(9):1080-5.

24. Prastiwi R, Elya B, Sauriasari R, Muhammad H, Ema D. Pharmacognosy, Phytochemical Study and Antioxidant Activity of Sterculia rubiginosa Zoll. Ex Miq. Leaves. Pharmacogn J. 2018;10(3):571-5.

\section{SUMMARY}

- The present study provides information about the chemical composition and the antioxidant activity of $M$. rotundifolia extracts

\section{GRAPHICAL ABSTRACT}

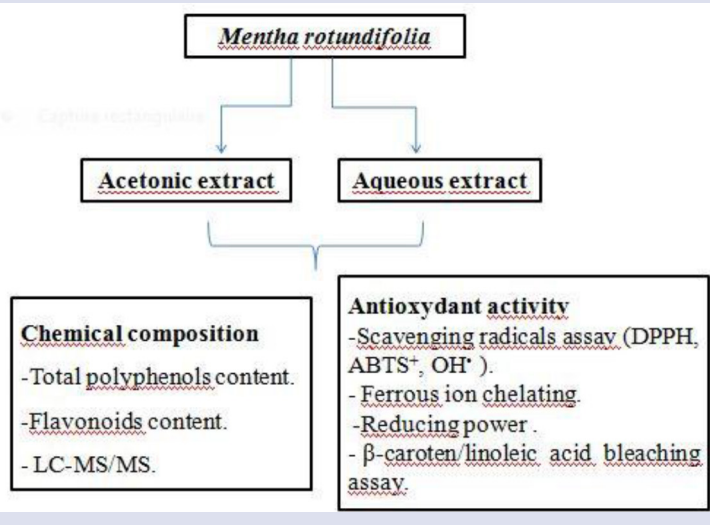

Cite this article: Siham F, Rachid B, Al-Zoubi RM. Chemical Composition and Antioxidant Effect of Mentha rotundifolia Extracts. Pharmacog J. 2019;11(3):521-6. 